\title{
Data report: IODP Expedition 339 Site U1391: an improved splice and preliminary age model on the basis of XRF data ${ }^{1}$
}

\author{
F. Abrantes, ${ }^{2,3,4}$ C. Santos, ${ }^{2,3,4,5}$ C. Ventura, ${ }^{2,3}$ A. Voelker, ${ }^{2,4}$ and U. Röhl ${ }^{5}$
}

\section{Chapter contents}

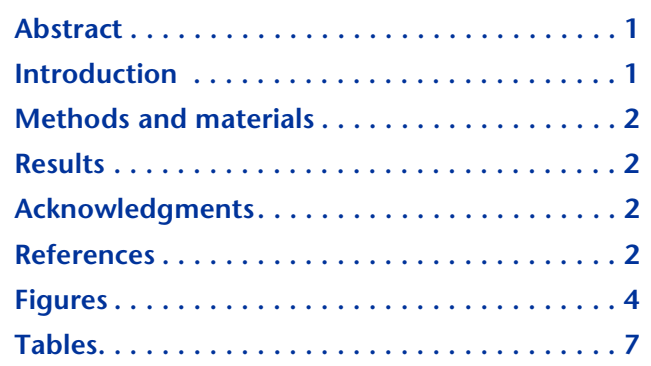

${ }^{1}$ Abrantes, F., Santos, C., Ventura, C., Voelker, A., and Röhl, U., 2017. Data report: IODP Expedition 339 Site U1391: an improved splice and preliminary age model on the basis of XRF data. In Stow, D.A.V., Hernández-Molina, F.J., Alvarez Zarikian, C.A., and the Expedition 339 Scientists, Proceedings of the Integrated Ocean Drilling Program, 339: Tokyo (Integrated Ocean Drilling Program Management International, Inc.). doi:10.2204/iodp.proc.339.203.2017

2Divisão de Geologia e Georecursos Marinhos, Instituto Português do Mar e da Atmosfera (IPMA), Rua Alfredo Magalhães Ramalho 6, 1495-006 Lisboa, Portugal. Correspondence author: fatima.abrantes@ipma.pt

${ }^{3}$ Also at CIIMAR, Universidade do Porto, Rua dos Bragas 287, 4050-123 Porto, Portugal.

${ }^{4}$ Also at CCMAR, Centro de Ciencias do Mar, Universidade do Algarve, Campus de Gambelas, 8005-139 Faro, Portugal.

${ }^{5}$ MARUM, Universität Bremen, Leobener Strasse, 28355 Bremen, Germany.

\section{Abstract}

With the objective to reconstruct past primary production on the southwest Portuguese margin at orbital and millennial timescales through the Pleistocene, we chose to compare two sites recovered during Expedition 339 at similar latitude but different distances to the coast (Sites U1385 and U1391). Site U1385 has a well-established chronology, but for Site U1391 no isotope data are yet available. In order to develop a correct chronology without isotope data, we performed XRF analysis of cores from Holes U1391A and U1391B between 76.51 and 205.77 mbsf. With these data, in particular using $\log (\mathrm{Ca} / \mathrm{Ti})$ and $\log (\mathrm{Ca} / \mathrm{Fe})$, it was possible to enhance the Site U1391 splice and to establish an age model based on the correlation to the well-defined and robust Site U1385 age model.

\section{Introduction}

During November 2011, Integrated Ocean Drilling Program (IODP) Expedition 339 departed from Ponta-Delgada/Azores, Portugal, with the main purpose of drilling in the Gulf of Cádiz to investigate tectonic and climatic control on the evolution of the Mediterranean Outflow. Furthermore, Site U1385 (Shackleton site) drilled off the southwest Portuguese margin, was expected to provide the possibility to extend back to the Pliocene, the bipolar record recognized in the area by Shackleton et al. (2000). At the end of the expedition, another core was drilled at about the same latitude as Site U1385 but closer to the coast, Site U1391 (see the "Expedition 339 summary" chapter [Expedition 339 Scientists, 2013]).

The Portuguese margin's location makes it an important spot to investigate the impact of global climate conditions on the regional processes, be it primary production resulting from the coastal upwelling conditions generated by the Iberian-Canary upwelling system; the surface, intermediate, and bottom water strength and chemical characteristics; or ecosystem behavior. To do so, in particular to allow for intercore and global comparison of the many proxy data being produced, it is basic that the respective site's splice is as precise as possible and that an accurate age model can be established. The Site U1385 splice was improved on the basis of the X-ray fluorescence (XRF) data, and its age model, mainly based on the benthic foraminifer oxygen isotope record, 
has been an object of extensive verification (Hodell et al., 2015). In order to improve the splice definition and age model for Site U1391, we have run XRF analysis on cores from Holes U1391A and U1391B between 76.51 and 205.77 meters below seafloor (mbsf) (81.47-235.53 meters composite depth [mcd]). This manuscript reports on the correction applied to the shipboard Site U1391 splice based on XRF data. Furthermore, it presents a preliminary age model defined through the correlation to the welldated Site U1385 $\log (\mathrm{Ca} / \mathrm{Ti})$ record.

\section{Methods and materials}

Site U1391 is located off southwestern Iberia $\left(37^{\circ} 21.5322^{\prime} \mathrm{N}, 9^{\circ} 24.6558^{\prime} \mathrm{W} ; 1085 \mathrm{~m}\right.$ water depth). Three holes were drilled. Holes U1391A and U1391B reached 353 mbsf, whereas in Hole U1391C, sediment was washed out to $340 \mathrm{mbsf}$ followed by rotary drilling to 671.5 mbsf.

XRF measurements were performed at $3 \mathrm{~cm}$ resolution along the shipboard-defined splice between 76.51 and 205.77 mbsf (81.47-235.53 mcd) with an AVAATECH scanner at the Center for Marine Environmental Sciences (MARUM) at the University of Bremen (Germany) following procedures in Röhl and Abrams (2000). This nondestructive analytical method determines the major and minor elements present in the sediments.

Following the example of the methodology applied for Site U1385 (Hodell et al., 2015), we used the $\log (\mathrm{Ca} / \mathrm{Ti})$ combined with the $\log (\mathrm{Ca} / \mathrm{Fe})$ to improve the shipboard defined splice.

\section{Results}

The unavoidable need for a precise age model before any reconstruction of past conditions is regularly fulfilled by a combination of dating methods. For Pleistocene sedimentary sequences, correlation of the benthic foraminifer oxygen isotopic record to the LR04 $\delta^{18} \mathrm{O}$ stack published by Lisiecki and Raymo (2005) is the most usual. In the absence of an isotopic record for Site U1391, a correlation to Site U1385, which has a well-established and robust chronology through a common parameter, was a possible way to circumvent the chronology problem. At Site U1385, the $\log (\mathrm{Ca} / \mathrm{Ti})$ signal shows good correspondence to the planktonic $\delta^{18} \mathrm{O}$ record (Hodell et al., 2015) and was therefore our selected parameter.

The $\log$ for $\mathrm{Ca} / \mathrm{Ti}$ and $\mathrm{Ca} / \mathrm{Fe}$ measured along the cores of Holes U1391A and U1391B that compose the shipboard splice of Site U1391 revealed the exis- tence of overlaps, offsets, and gaps. To fill in the gaps and in some cases to pinpoint the extension of some overlaps, new measurements were done on adjoining core sections and both $\log (\mathrm{Ca} / \mathrm{Ti})$ and $\log (\mathrm{Ca} / \mathrm{Fe})$ were used to determine the correction to apply to the mcd depth scale. Figure F1 shows the obtained $\log (\mathrm{Ca} / \mathrm{Ti})$ record for Site U1391 between 81.47 and 235.53 mcd (on board) and the corrected composite depth (cmcd). Figure F2 shows the $\log (\mathrm{Ca} / \mathrm{Ti})$ and $\log (\mathrm{Ca} / \mathrm{Fe})$ for shipboard mcd and corrected cmcd for the two intervals where major mismatch was detected between 160 and 180 mcd (Fig. F2A, F2B) and from 230 to $250 \mathrm{mcd}$ (Fig. F2C, F2D). Table T1 reports the applied correction to the shipboard defined mcd to obtain the new cmcd.

For the definition of a preliminary chronology for Site U1391, the record obtained after the mcd correction was correlated to the $\log (\mathrm{Ca} / \mathrm{Ti})$ of Site U1385, which has a well-defined chronology (Hodell et al., 2015). This was performed using the Analyseries program (Paillard et al., 1996) and reveals a complete sequence between marine isotope Stages (MIS) 9 and 22. Figure $\mathbf{F} 3$ shows $\log (\mathrm{Ca} / \mathrm{Ti})$ versus age at the two sites (U1385 and U1391) and the benthic isotopic reference record of Lisiecki and Raymo (2005). Table T2 contains the tie points used.

\section{Acknowledgments}

The authors acknowledge the Integrated Ocean Drilling Program (2003-2013) for allowing the analysis of the cores from Holes U1391A and U1391B. The study was funded by the Fundação para a Ciência e a Tecnologia (FCT) through project DiatBio (PTDC/ AAG-GLO/3737/2012). Thanks are also due to Vera Lukies and Thomas Westerhold for their support during the XRF analysis at MARUM.

\section{References}

Expedition 339 Scientists, 2013. Expedition 339 summary. In Stow, D.A.V., Hernández-Molina, F.J., Alvarez Zarikian, C.A., and the Expedition 339 Scientists, Proceedings of the Integrated Ocean Drilling Program, 339: Tokyo (Integrated Ocean Drilling Program Management International, Inc.). http://dx.doi.org/10.2204/ iodp.proc.339.101.2013

Hodell, D., Lourens, L., Crowhurst, S., Konijnendijk, T., Tjallingii, R., Jiménez-Espejo, F., Skinner, L., Tzedakis, P.C., and Shackleton Site Project Members, 2015. A reference time scale for Site U1385 (Shackleton site) on the SW Iberian margin. Global and Planetary Change, 133:49-64. http://dx.doi.org/10.1016/j.gloplacha.2015.07.002 
Lisiecki, L.E., and Raymo, M.E., 2005. A Pliocene-Pleistocene stack of 57 globally distributed benthic $\delta^{18} \mathrm{O}$ records. Paleoceanography, 20(1):PA1003. http:// dx.doi.org/10.1029/2004PA001071

Paillard, D., Labeyrie, L., and Yiou, P., 1996. Macintosh program performs time-series analysis. Eos, Transactions of the American Geophysical Union, 77(39):379. http:// dx.doi.org/10.1029/96EO00259

Röhl, U., and Abrams, L.J., 2000. High-resolution, downhole, and nondestructive core measurements from Sites 999 and 1001 in the Caribbean Sea: application to the late Paleocene Thermal Maximum. In Leckie, R.M., Sigurdsson, H., Acton, G.D., and Draper, G. (Eds.), Proceed- ings of the Ocean Drilling Program, Scientific Results, 165: College Station, TX (Ocean Drilling Program), 191-203. http://dx.doi.org/10.2973/odp.proc.sr.165.009.2000

Shackleton, N.J., Hall, M.A., and Vincent, E., 2000. Phase relationships between millennial-scale events 64,000 24,000 years ago. Paleoceanography, 15(6):565-569. http://dx.doi.org/10.1029/2000PA000513

Initial receipt: 10 March 2016

Acceptance: 5 January 2017

Publication: 28 February 2017

MS 339-203 
Figure F1. Log Ca/Ti record between 81.47 and $235.53 \mathrm{mcd}$ and on the corrected composite depth scale (cmcd), Site U1391.
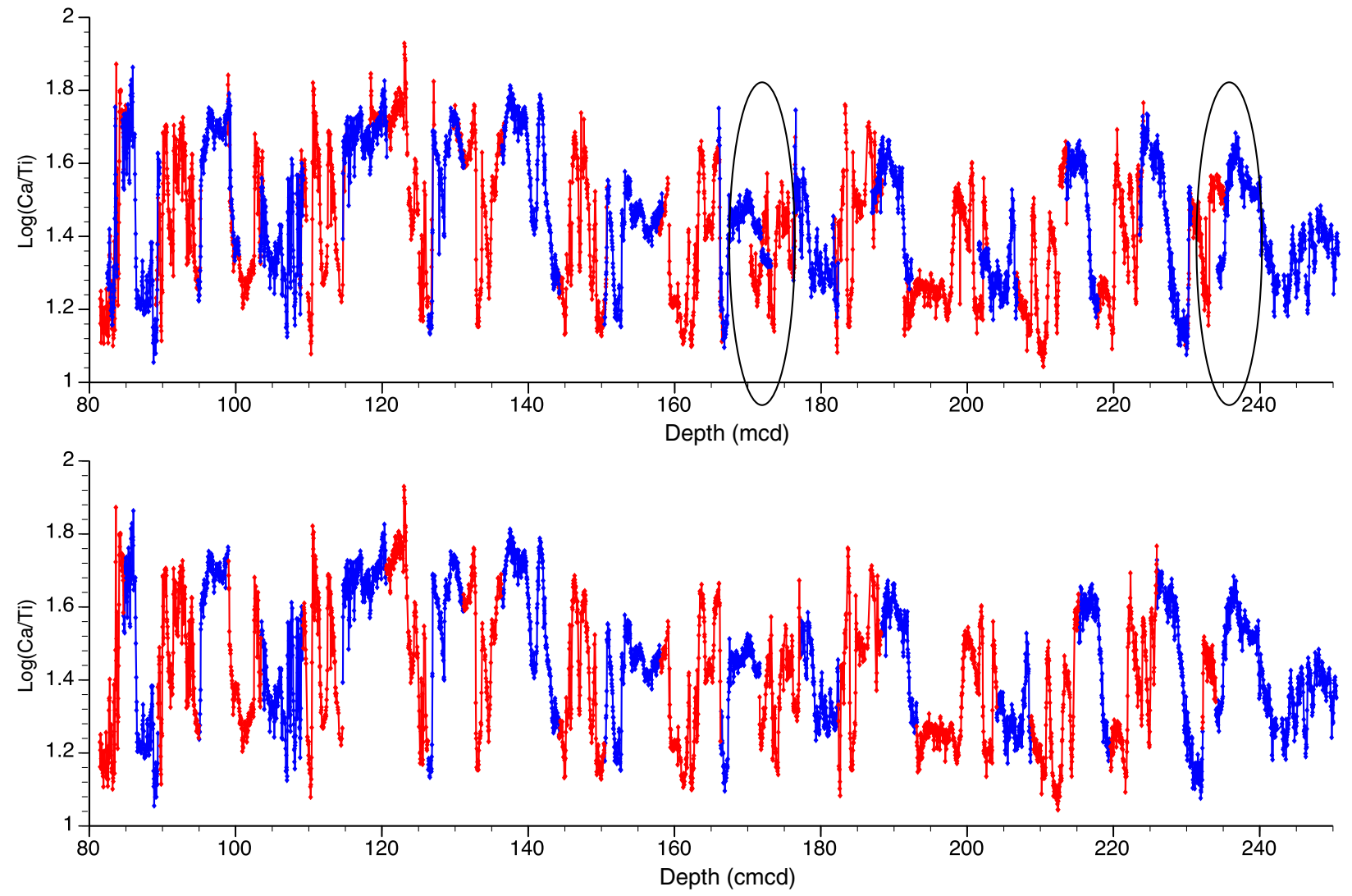
Figure F2. A-D. Log Ca/Ti and Ca/Fe on mcd and cmcd depth scales for the two intervals where major overlap was identified on the shipboard splice, Site U1391.
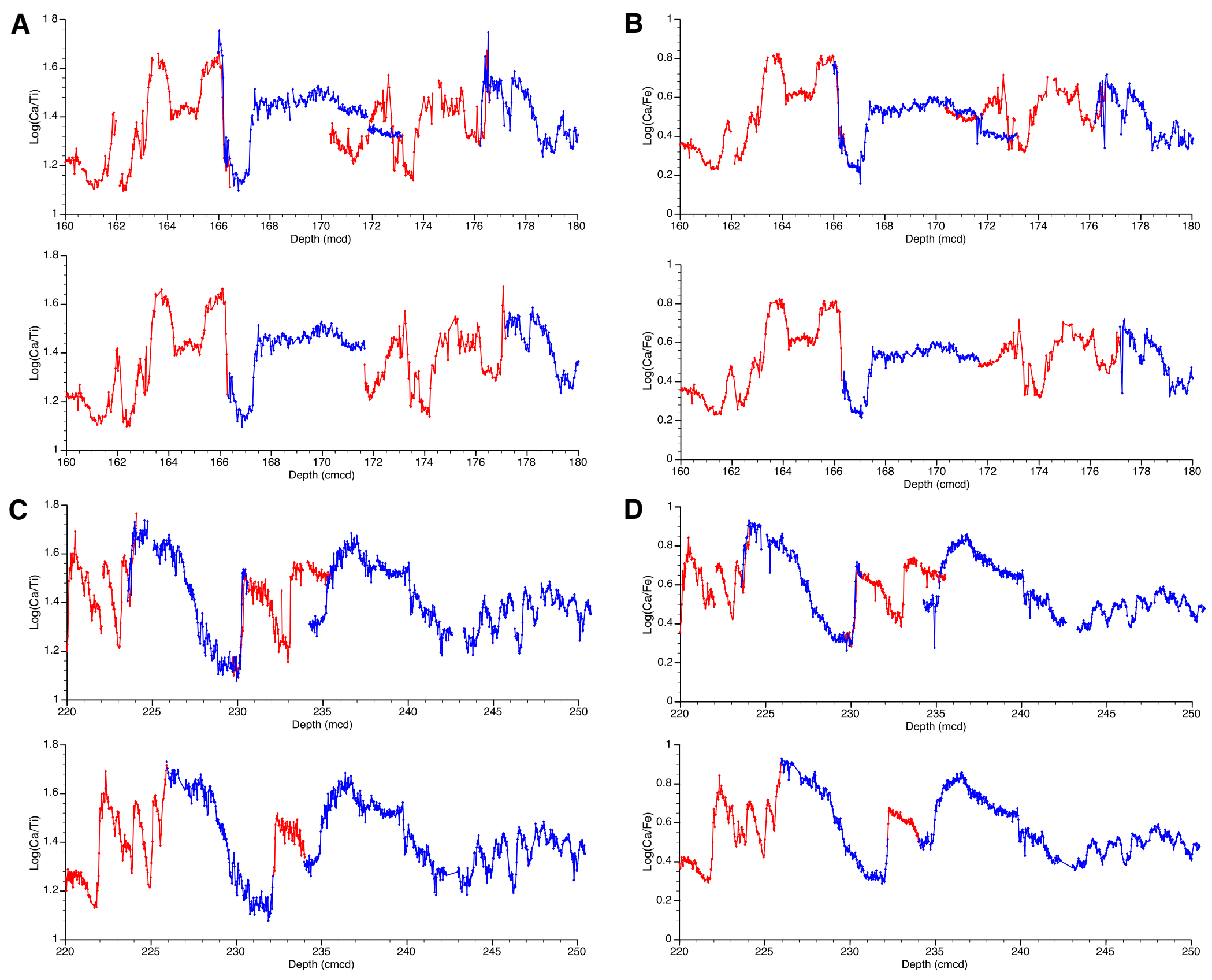
Figure F3. Log Ca/Ti records plotted on age for both Sites U1385 and U1391 with the LR04 $\delta^{18} \mathrm{O}$ stack for comparison. $\mathrm{BP}=$ before present.

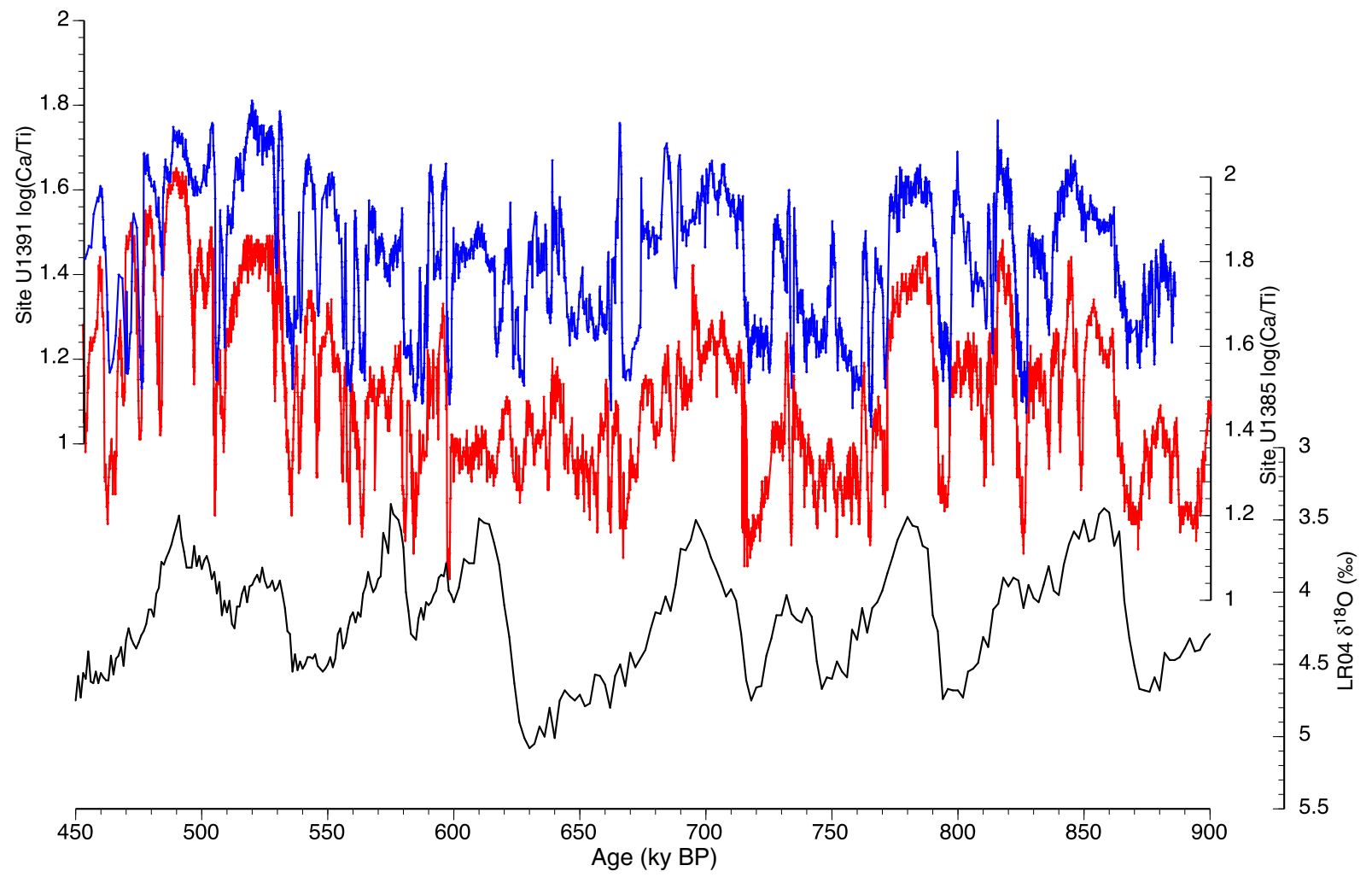


Table T1. Shipboard composite and corrected composite depths, Holes U1391A, U1391B.

\begin{tabular}{|c|c|c|c|c|c|c|}
\hline $\begin{array}{l}\text { Core, section, } \\
\text { interval }(\mathrm{cm})\end{array}$ & $\begin{array}{l}\text { Depth } \\
\text { (mbsf) }\end{array}$ & $\begin{array}{l}\text { Depth } \\
\text { (mcd) }\end{array}$ & $\begin{array}{c}\text { Offset } \\
\text { (mcd - mbsf) }\end{array}$ & $\begin{array}{c}\text { Offset } \\
\text { (cmcd - mcd) }\end{array}$ & $\begin{array}{c}\text { Offset } \\
(\mathrm{mbsf}-\mathrm{cmcd})\end{array}$ & $\begin{array}{l}\text { Depth } \\
\text { (cmcd) }\end{array}$ \\
\hline \multicolumn{7}{|l|}{ 339-U1391A- } \\
\hline $9 \mathrm{H}-5,3$ & 76.51 & 81.47 & 4.96 & 0.00 & 4.96 & 81.47 \\
\hline $9 \mathrm{H}-7,36$ & 79.72 & 84.68 & 4.96 & 0.00 & 4.96 & 84.68 \\
\hline $10 \mathrm{H}-2,122$ & 82.74 & 89.39 & 6.65 & 0.00 & 6.65 & 89.39 \\
\hline $10 \mathrm{H}-6,112$ & 88.36 & 95.01 & 6.65 & 0.00 & 6.65 & 95.01 \\
\hline $11 \mathrm{H}-2,24$ & 91.25 & 99.06 & 7.81 & 0.00 & 7.81 & 99.06 \\
\hline $11 \mathrm{H}-5,54$ & 95.67 & 103.48 & 7.81 & 0.00 & 7.81 & 103.48 \\
\hline $12 \mathrm{H}-2,82$ & 100.51 & 109.23 & 8.72 & 0.00 & 8.72 & 109.23 \\
\hline $12 \mathrm{H}-6,83$ & 105.90 & 114.62 & 8.72 & 0.00 & 8.72 & 114.62 \\
\hline $13 \mathrm{H}-2,111$ & 110.85 & 120.60 & 9.75 & 0.00 & 9.75 & 120.60 \\
\hline $13 \mathrm{H}-6,135$ & 116.55 & 126.30 & 9.75 & 0.00 & 9.75 & 126.30 \\
\hline $14 \mathrm{H}-2,6$ & 119.59 & 131.20 & 11.61 & 0.00 & 11.61 & 131.20 \\
\hline $14 \mathrm{H}-5,93$ & 124.73 & 136.34 & 11.61 & 0.00 & 11.61 & 136.34 \\
\hline $15 \mathrm{H}-1,111$ & 128.71 & 144.25 & 15.54 & 0.00 & 15.54 & 144.25 \\
\hline $15 \mathrm{H}-6,18$ & 134.91 & 150.45 & 15.54 & 0.00 & 15.54 & 150.45 \\
\hline $16 \mathrm{H}-2,30$ & 137.83 & 158.07 & 20.24 & 0.09 & 20.33 & 158.16 \\
\hline $16 \mathrm{H}-7,120$ & 145.96 & 166.20 & 20.24 & 0.09 & 20.33 & 166.29 \\
\hline $17 \mathrm{H}-1,73$ & 147.33 & 171.06 & 23.73 & 0.59 & 24.32 & 171.65 \\
\hline $17 \mathrm{H}-5,60$ & 152.84 & 176.57 & 23.73 & 0.59 & 24.32 & 177.16 \\
\hline $18 \mathrm{H}-2,12$ & 157.25 & 181.98 & 24.73 & 0.44 & 25.17 & 182.415 \\
\hline $18 \mathrm{H}-6,51$ & 163.09 & 187.82 & 24.73 & 0.44 & 25.17 & 188.255 \\
\hline $19 \mathrm{H}-1,45$ & 166.05 & 191.78 & 25.73 & 1.34 & 27.07 & 193.12 \\
\hline $20 X-4,138$ & 176.98 & 202.71 & 25.73 & 1.34 & 27.07 & 204.05 \\
\hline $21 X-1,3$ & 180.73 & 206.71 & 25.98 & 2.05 & 28.03 & 208.76 \\
\hline $21 X-5,57$ & 187.20 & 213.18 & 25.98 & 2.05 & 28.03 & 215.23 \\
\hline $22 X-2,102$ & 191.77 & 217.74 & 25.97 & 1.87 & 27.84 & 219.61 \\
\hline $22 X-7,72$ & 198.10 & 224.07 & 25.97 & 1.87 & 27.84 & 225.94 \\
\hline $23 X-1,69$ & 200.49 & 230.25 & 29.76 & 1.93 & 31.69 & 232.18 \\
\hline $23 X-2,102$ & 202.32 & 232.08 & 29.76 & 1.93 & 31.69 & 234.01 \\
\hline \multicolumn{7}{|l|}{ 339-U1391B- } \\
\hline $9 \mathrm{H}-3,76$ & 79.59 & 84.58 & 4.99 & 0.10 & 5.09 & 84.68 \\
\hline $9 \mathrm{H}-6,114$ & 84.28 & 89.27 & 4.99 & 0.10 & 5.09 & 89.37 \\
\hline $10 \mathrm{H}-3,42$ & 88.57 & 95.02 & 6.45 & 0.00 & 6.45 & 95.02 \\
\hline $10 \mathrm{H}-6,1$ & 92.55 & 99.00 & 6.45 & 0.00 & 6.45 & 99.00 \\
\hline $11 \mathrm{H}-1,84$ & 95.84 & 103.49 & 7.65 & 0.00 & 7.65 & 103.49 \\
\hline $11 \mathrm{H}-5,92$ & 101.58 & 109.23 & 7.65 & 0.00 & 7.65 & 109.23 \\
\hline $12 \mathrm{H}-1,105$ & 105.55 & 114.64 & 9.09 & 0.00 & 9.09 & 114.64 \\
\hline $12 \mathrm{H}-5,129$ & 111.45 & 120.54 & 9.09 & 0.00 & 9.09 & 120.54 \\
\hline $13 \mathrm{H}-3,3$ & 116.85 & 126.32 & 9.47 & 0.00 & 9.47 & 126.32 \\
\hline $13 \mathrm{H}-6,63$ & 121.70 & 131.17 & 9.47 & 0.00 & 9.47 & 131.17 \\
\hline $14 \mathrm{H}-1,42$ & 123.92 & 136.39 & 12.47 & 0.00 & 12.47 & 136.39 \\
\hline $14 \mathrm{H}-6,113$ & 131.75 & 144.22 & 12.47 & 0.00 & 12.47 & 144.22 \\
\hline $15 \mathrm{H}-2,78$ & 134.21 & 150.47 & 16.26 & 0.00 & 16.26 & 150.47 \\
\hline $15 \mathrm{H}-7,117$ & 141.81 & 158.07 & 16.26 & 0.00 & 16.26 & 158.07 \\
\hline $16 \mathrm{H}-2,30$ & 144.22 & 166.23 & 22.01 & 0.09 & 22.10 & 166.32 \\
\hline $16 \mathrm{H}-5,123$ & 149.55 & 171.56 & 22.01 & 0.09 & 22.10 & 171.65 \\
\hline $17 \mathrm{H}-1,69$ & 152.69 & 176.50 & 23.81 & 0.66 & 24.47 & 177.16 \\
\hline $17 \mathrm{H}-5,21$ & 157.96 & 181.77 & 23.81 & 0.66 & 24.47 & 182.43 \\
\hline $18 \mathrm{H}-1,63$ & 162.13 & 187.55 & 25.42 & 0.72 & 26.14 & 188.27 \\
\hline $18 \mathrm{H}-4,144$ & 166.98 & 192.40 & 25.42 & 0.72 & 26.14 & 193.12 \\
\hline $20 x-2,6$ & 176.02 & 202.05 & 26.03 & 2.00 & 28.03 & 204.05 \\
\hline $20 X-5,27$ & 180.73 & 206.76 & 26.03 & 2.00 & 28.03 & 208.76 \\
\hline $21 X-1,78$ & 185.88 & 213.50 & 27.62 & 1.73 & 29.35 & 215.23 \\
\hline $21 X-4,90$ & 190.26 & 217.88 & 27.62 & 1.73 & 29.35 & 219.61 \\
\hline $22 X-1,45$ & 195.05 & 223.97 & 28.92 & 1.97 & 30.89 & 225.94 \\
\hline $22 X-5,69$ & 201.29 & 230.21 & 28.92 & 1.97 & 30.89 & 232.18 \\
\hline $23 X-1,63$ & 204.83 & 234.25 & 29.42 & -0.24 & 29.18 & 234.01 \\
\hline $24 X-5,149$ & 221.29 & 250.71 & 29.42 & -0.24 & 29.18 & 250.47 \\
\hline
\end{tabular}


Table T2. Tie points used to establish the Site U1391 age model on the basis of correlation to the well-dated age model at Site U1385 obtained through Ca/Ti values and the LR04 $\delta^{18} \mathrm{O}$ stack (Lisiecki and Raymo, 2005).

\begin{tabular}{rr}
\hline $\begin{array}{c}\text { Site U1391 } \\
\text { depth (cmcd) }\end{array}$ & $\begin{array}{c}\text { Site U1385 age } \\
\text { (ky BP) }\end{array}$ \\
\hline 81.64 & 269.19 \\
86.40 & 287.23 \\
86.68 & 288.84 \\
87.44 & 289.92 \\
87.81 & 290.88 \\
88.76 & 293.92 \\
89.72 & 297.56 \\
90.70 & 301.87 \\
91.50 & 303.30 \\
94.27 & 312.58 \\
99.15 & 331.66 \\
100.88 & 335.33 \\
102.53 & 340.13 \\
103.21 & 345.11 \\
103.78 & 349.01 \\
105.61 & 353.32 \\
107.07 & 356.15 \\
107.43 & 362.30 \\
107.88 & 364.86 \\
108.91 & 369.25 \\
109.59 & 374.64 \\
110.47 & 375.89 \\
110.71 & 380.48 \\
110.87 & 382.18 \\
111.50 & 386.97 \\
112.58 & 388.72 \\
112.95 & 392.54 \\
114.66 & 395.37 \\
123.62 & 429.29 \\
124.50 & 456.48 \\
125.24 & 459.98 \\
125.52 & 466.63 \\
125.99 & 471.96 \\
126.90 & 473.71 \\
127.78 & 478.56 \\
128.48 & 481.16 \\
132.83 & 502.37 \\
134.91 & 506.77 \\
139.69 & 525.53 \\
141.25 & 527.37 \\
142.11 & 529.30 \\
145.08 & 533.34 \\
145.75 & 535.98 \\
147.02 & 543.44 \\
&
\end{tabular}

\begin{tabular}{cc}
\hline $\begin{array}{c}\text { Site U1391 } \\
\text { depth (cmcd) }\end{array}$ & $\begin{array}{c}\text { Site U1385 age } \\
(\mathrm{ky} \mathrm{BP})\end{array}$ \\
\hline 148.29 & 552.81 \\
148.97 & 553.99 \\
152.74 & 562.23 \\
153.96 & 566.19 \\
156.79 & 571.78 \\
159.28 & 577.22 \\
166.17 & 594.54 \\
167.32 & 596.69 \\
173.31 & 620.43 \\
174.26 & 625.95 \\
176.16 & 634.48 \\
179.01 & 641.84 \\
181.18 & 655.52 \\
182.38 & 659.34 \\
184.09 & 664.91 \\
184.70 & 671.72 \\
185.73 & 677.51 \\
186.54 & 680.60 \\
187.52 & 684.78 \\
187.87 & 688.68 \\
189.42 & 702.81 \\
191.28 & 710.57 \\
191.87 & 712.99 \\
199.22 & 724.35 \\
202.18 & 731.76 \\
203.51 & 733.18 \\
205.61 & 738.49 \\
208.65 & 750.74 \\
210.16 & 756.39 \\
210.80 & 760.29 \\
211.36 & 762.85 \\
213.03 & 764.60 \\
214.60 & 770.84 \\
218.55 & 791.25 \\
221.90 & 795.69 \\
223.32 & 804.44 \\
223.93 & 810.50 \\
229.47 & 821.54 \\
232.27 & 826.52 \\
233.92 & 834.06 \\
& 836.03 \\
\hline & 861.11 \\
234.93 & 872.56 \\
\hline
\end{tabular}

